\title{
頻骨囊胞壁の血管走行について
}

\author{
横林康男
}

\section{Arrangement of blood vessels in the wall of jaw cysts}

\author{
Yasuo YOKOBAYASHI
}

\begin{abstract}
The arrangement of blood vessels in the cyst wall was studied in 10 radicular cysts, 10 old radicular cysts, 5 non-keratinizing primordial cysts, 5 odontogenic keratocysts, 5 dentigerous cysts and 5 nasopalatine duct cysts.

The majority of blood vessels in the cyst wall were consisted of capillaries (68.8\%) and venules $(25.3 \%)$ and there was no statistical difference in the distribution of constituent vessels between inflammatory cysts and developmental cysts.

The deepest layer of the cyst wall showed the highest incidence of inflammation which decreased gradually towards the outer layer in both inflammatory and developmental cysts. However this tendency was more conspicuous in inflammatory cysts and there was no section in which histological evidence of inflammation was not noted in the deepest layer of the inflammatory cysts.

In both groups of cysts, the number of capillaries increased in a similar degree in the presence of inflammation. Furthermore, there was no difference in the number of blood vessels among different layers between the two cyst types when inflammation was present. Blood vessels were distributed more densely in the inner layer of the developmental cysts in sections with no evidence of inflammatory response, but this was not the case in the inflammatory cysts.
\end{abstract}

When blood vessels in the cyst wall were divided into vertical and horizontal types by the angle made to the lining epithelium, the vertical type blood vessels increased in the presence of inflammation. The basic pattern of vascular arrangement in the inflammatory cysts was the predominance of vertical type in the deepest layer and horizontal type in the superficial layer. Despite the increase in the ratio of horizontal blood vessels, vertical type predominance was maintained even after inflammation subsided in the deepest layer. On the other hand, the cyst wall of the developmental cysts was consisted mainly of horizontal type blood vessels. In the presence of inflammation, the vertical type increased, but the horizontal type still predominanted in the deepest layer, whereas in the superficial layer the vertical type surpassed the horizontal type in most cysts.

The results indicate that analysis of vascular arrangement in the cyst wall may be of help in the differential diagnosis of inflammatory cysts and developmental cysts.

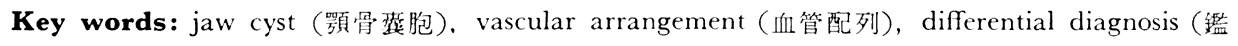
別診断)

新潟大学菌学部口腔外科学第 1 教室

（主任：中島民雄教授）

First Department of Oral and Maxillofacial Sur- gery, School of Dentistry Niigata University (Chief: Prof. Tamio Nakajima)

受付日：平成元年 8 月31日 


\section{緒}

言

顎骨には，他の骨に比較して非常に多くの露胞が発生

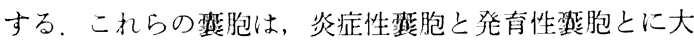
別されているが1 3)，央際には発育性䗸胞の多くは自覚 症状がなく感染が加わってはじめて発見されるため, 病 理組織学的には炎症性艇胞との鑑別が困難なことが少な くない4).

横林や福帛 $5^{5,6)}$ は, 露胞壁の上皮下組織の細血管に着 目し，その走行は炎症性整胞では裏層上皮に対してほほ 垂直に走る「維型」が基本であるのに対し，発育性垶胞 では裏層上皮と並行する「水平型」が特徽であると述べ ている，以上の所見は，整胞壁の血管走行もその発生や

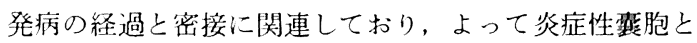
発有性䨋胞の鑑別診断の一助となり得ることを示唆して いるものと思われる。しかし，彼らの行った分析は定性 的なもので，炎症性翼胞および発育性露胞の血管走行の 違いについて定量的に検討した報告はいまたみられな い

そこで今回，露胞壁の病理組織切片上での血管の断面 より整胞内腔面に対する血管の走行角度を求める方法を

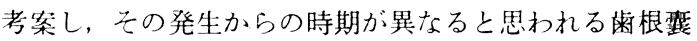

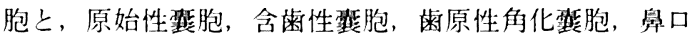
蓋管整胞などの発育性整胞について分析したところ，い くつかの興味ある知見を得たので報告する.

\section{研 究 対 象}

対象は, 新潟大学雪学部附属病院において取り扱った 䪽骨跱胞で，その内訳は臨床，X線および病理組織所見

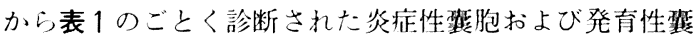
胞各20例である。

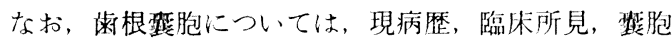
の大きさ, 病理所見での重層上皮, 炎症性細胞浸潤の状
態, 線維成分の多少, 粘液紐胞化生の有無などを総合し

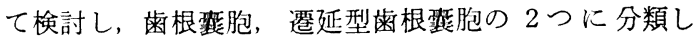
た。なわち，雨牙嫨蝕の自覚ないし処置後数年以上経 過し，裏層上皮は上皮突起が少ない非角化型扁平上皮 で，経過の長さを示すと考えられる粘液細胞化生や線毛 緗胞化生を認め, 炎症が比較的少ないものを遷延型曾根 露胞とした。

また，炎怔性烮胞群では臨床的に急性炎症の既往があ るか, あるいは初診時に炎症症状が認められたものは, 70〜100\%であったが，病理組織学的には遷延型雪根雚 胞の 2 例を除いたすべてに炎症性紐胞浸潤と肉芽層の存 在がみられた。一方, 発育性整胞でも臨床的に炎症があ ったものは40〜100\%あり，病理組織学的所見では炎症 性細胞浸潤は20例中19例に，また肉芽層も約半数に認め られた（表1）.

\section{研 究 方 法}

\section{1. 資料の作製}

摘出材料は，10\%ホルマリン固定後，パラフィン包埋 し，内腔面に対してできるだけ垂直に薄切し $(5 \mu \mathrm{m})$, H-E 染色して病理組織切片を作成した。なお, 薄切の際 の変形を補正するために, 薄切後の変形率をX軸, $\mathrm{Y}$ 軸 方向で計算しておいた。

次に，組織切片の顕微鏡写真を撮影し（対物レンズ10 $\mathrm{x}$, 接眼レンズ NFK 3.3x 使用) 一定倍率（フィルムの 約4.7倍）で大キャビネの印画紙に焼付け，血管の走行 角度分析の資料とした。

\section{2. 冥胞の内腔面に対する血管の走行角度の計算方法}

血管がほぼ円筒形の連続であると仮定すると，血管の 断面の基本形は円か楕円となる。血管の三次元的模式図 に执いて，線 OFは血管の軸を示しているＹY軸の正の 方向を賴胞壁の内側にとり，XOY 平面で標本を薄切 L,

$$
\angle \mathrm{FOG}=\alpha\left(0^{\circ} \leqq \alpha<180^{\circ}\right)
$$

表 1 対象症例の臨床・病理組織学的所見

\begin{tabular}{|c|c|c|c|c|c|c|}
\hline & \multicolumn{2}{|c|}{ 炎症性琵胞 } & \multicolumn{4}{|c|}{ 発青性婆胞 } \\
\hline & 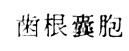 & 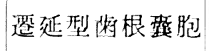 & 原始性涏胞 & 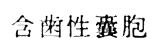 & 秚原性角化程胞 & 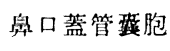 \\
\hline 症 例 数 & 10 & 10 & 5 & 5 & 5 & 5 \\
\hline 炎症の既往 & $7 / 10$ & $8 / 10$ & $5 / 5$ & $3 / 5$ & $2 / 5$ & $3 / 5$ \\
\hline $\begin{array}{l}\text { 初診時の炎症性 } \\
\text { 腫脹・疼痛 }\end{array}$ & $2 / 10$ & $8 / 10$ & $1 / 5$ & $1 / 5$ & $2 / 5$ & $2 / 5$ \\
\hline 孔 & $4 / 10$ & $2 / 10$ & $1 / 5$ & $0 / 5$ & $1 / 5$ & $0 / 5$ \\
\hline $\begin{array}{lll}\text { 炎症性 } & \text { 性溜 } \\
\text { 細 }\end{array}$ & $10 / 10$ & $10 / 10$ & $5 / 5$ & $4 / 5$ & $5 / 5$ & $5 / 5$ \\
\hline 肉芽愿 & $10 / 10$ & $8 / 10$ & $2 / 5$ & $2 / 5$ & $3 / 5$ & $3 / 5$ \\
\hline
\end{tabular}




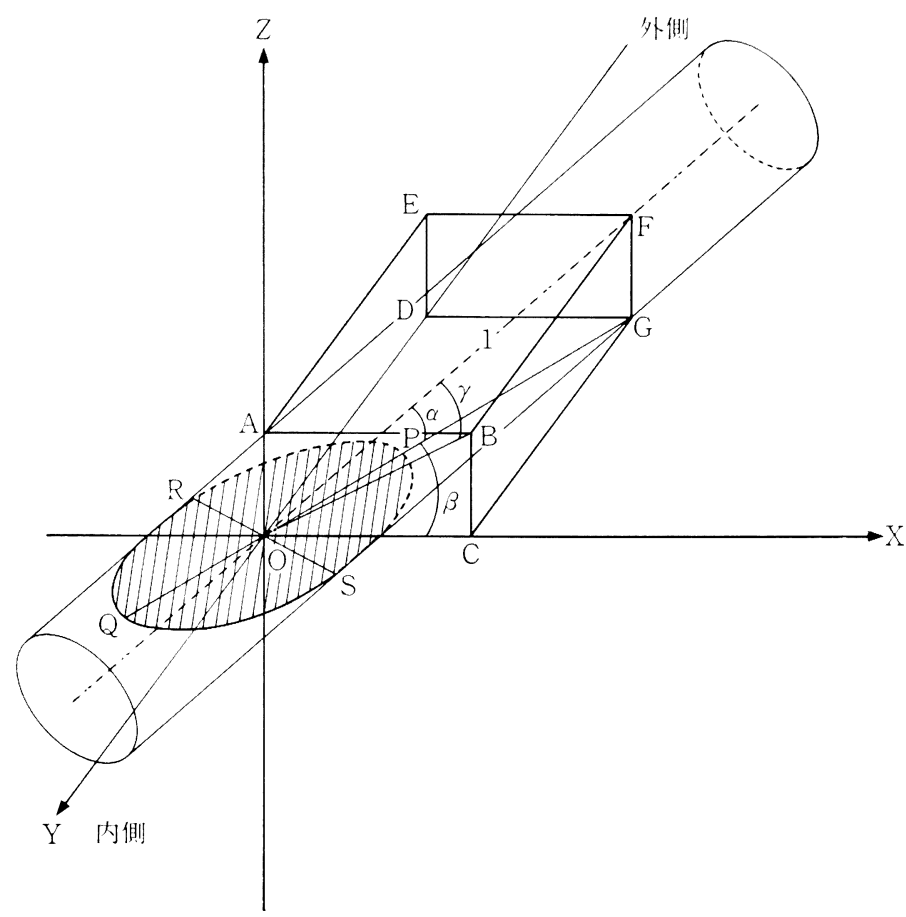

図 1 血管の三次元的模式図

$$
\begin{aligned}
& \angle \mathrm{GOC}=\beta\left(0^{\circ} \leqq \beta<180^{\circ}\right) \\
& \angle \mathrm{FOB}=\gamma\left(0^{\circ} \leqq \gamma<90^{\circ}\right)
\end{aligned}
$$

とすると， $\gamma$ は血管の軸と刑胞壁の内腔面とのなす角度 となる. $\overline{\mathrm{OB}}=\mathrm{C}_{3}, \overline{\mathrm{OF}}=1$ とおくと $\overline{\mathrm{OB}}=\mathrm{C}_{3}=\mathrm{COS} \gamma=$ $\sqrt{\overline{\mathrm{BC}^{2}}+\overline{\mathrm{OC}^{2}}}=\sqrt{\mathrm{FG}^{2}+\overline{\mathrm{OC}^{2}}}=\sqrt{\mathrm{SIN}^{2} \alpha+\mathrm{COS}^{2} \alpha \mathrm{COS}^{2} \beta}$ …...(1) となる（図1）.

平面 XOY での血管の断面に扎い, 血管の断面の 短径 $=\overline{\mathrm{RS}}=\sqrt{\mathrm{C}_{1}}$, 長径 $=\overline{\mathrm{PQ}}=\sqrt{\mathrm{C}_{2}}$ とおくと, $\mathrm{C}_{1}=$ $\left(\mathrm{x}_{3}-\mathrm{x}_{4}\right)^{2}+\left(\mathrm{y}_{3}-\mathrm{y}_{4}\right)^{2}, \quad \mathrm{C}_{2}=\left(\mathrm{x}_{1}-\mathrm{x}_{2}\right)^{2}+\left(\mathrm{y}_{1}-\mathrm{y}_{2}\right)^{2}$ とな 万(図 2 ).

血管の軸を通り XOY 平面に垂直な方向で切った血 管の綖断面において，PQは，長径だから， $\overline{\mathrm{PQ}}=$ $\sqrt{\mathrm{C}_{2}}, \overline{\mathrm{QT}}=$ 短径 $=\sqrt{\mathrm{C}_{1}}, \operatorname{SIN} \alpha=\frac{\overline{\mathrm{QT}}}{\overline{\mathrm{PQ}}}=\frac{\sqrt{\mathrm{C}_{1}}}{\sqrt{\mathrm{C}_{2}}}, \operatorname{COS} \alpha=$ $\sqrt{1-\operatorname{SIN}^{2} \alpha=} \sqrt{1-\frac{\mathrm{C}_{1}}{\mathrm{C}_{2}}}, \quad \operatorname{COS} \beta=\frac{\mathrm{x}_{1}-\mathrm{x}_{2}}{\sqrt{\mathrm{C}_{2}}}$ となるから, これらの値を(1)の式に代入すると，

$$
\begin{aligned}
\mathrm{C}_{3}=\operatorname{COS} \gamma & =\sqrt{\frac{\mathrm{C}_{1}}{\mathrm{C}_{2}}+\left(1-\frac{\mathrm{C}_{1}}{\mathrm{C}_{2}}\right) \frac{\left(\mathrm{x}_{1}-\mathrm{x}_{2}\right)^{2}}{\mathrm{C}_{2}}} \\
& =\sqrt{\frac{\mathrm{C}_{1}}{\mathrm{C}_{2}}+\left(\frac{\mathrm{C}_{2}-\mathrm{C}_{1}}{\mathrm{C}_{2}}\right) \frac{\left(\mathrm{x}_{1}-\mathrm{x}_{2}\right)^{2}}{\mathrm{C}_{2}}} \\
& =\sqrt{\frac{\mathrm{C}_{1} \mathrm{C}_{2}+\left(\mathrm{C}_{2}-\mathrm{C}_{1}\right)\left(\mathrm{x}_{1}-\mathrm{x}_{2}\right)^{2}}{\mathrm{C}_{2}{ }^{2}}}
\end{aligned}
$$

(2) (図 3).

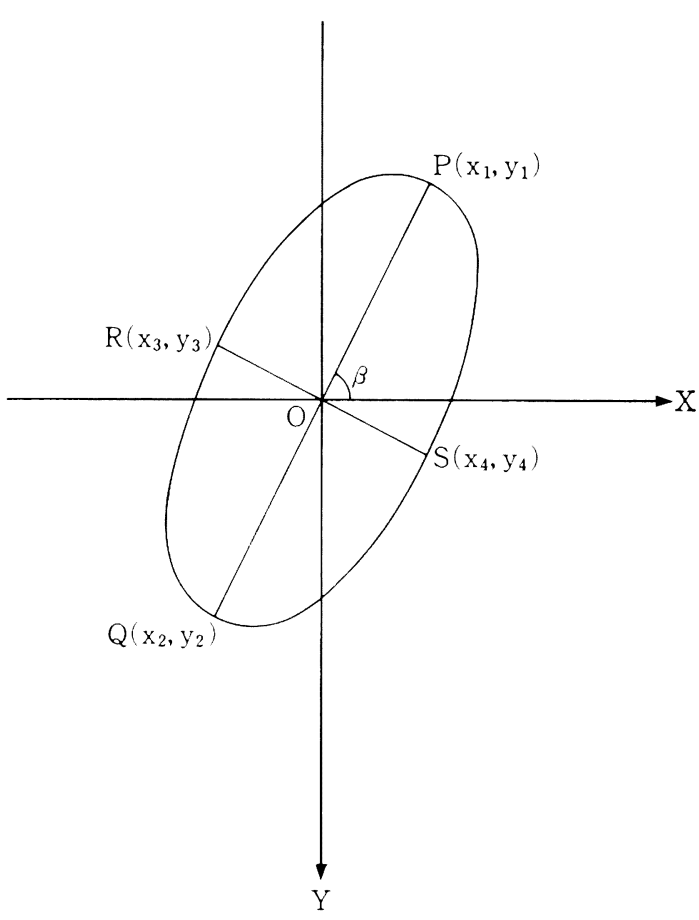

図 2 平面 XOY での血管の断面図 


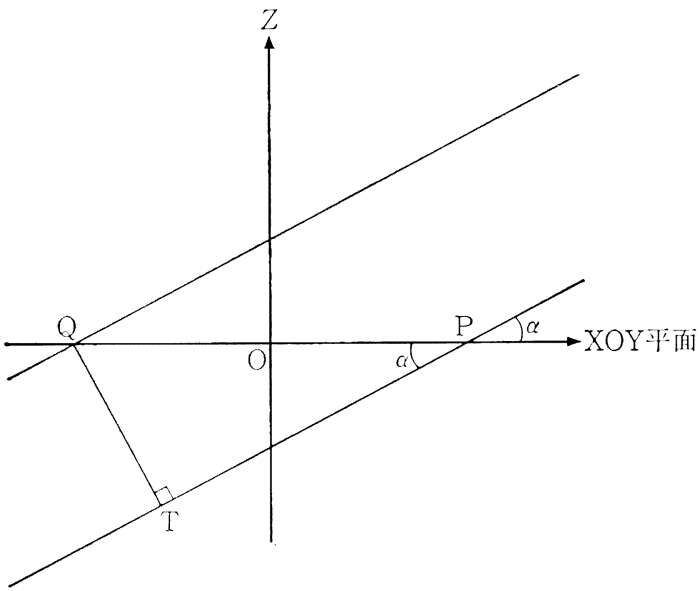

図 3 血管の樅断面図

$$
\begin{aligned}
& \operatorname{SIN}^{2} \gamma+\operatorname{COS}^{2} \gamma=1, \quad 0^{\circ} \leqq \gamma<90^{\circ} \text { より } \\
& \tan \gamma=\sqrt{\frac{1}{\operatorname{COS}^{2} \gamma}-1}=\sqrt{\frac{1-\mathrm{C}_{3}{ }^{2}}{\mathrm{C}_{3}{ }^{2}}} \\
& \therefore \gamma=\tan ^{-1} \sqrt{\frac{1-\mathrm{C}_{3}{ }^{2}}{\mathrm{C}_{3}{ }^{2}}}
\end{aligned}
$$

すなわち血管の断面の PQRS の各点の座標がわかれ ば，血管と嘎胞内腔面とのなす角度が求められるので, これをもとにプログラムを作成し，パーソナルコンピュ ータにて計算した。

\section{3. 使用機器}

写真撮影には,オリンパスシステム生物顕微鏡(BHS), レンズに NFK 撮影レンズ, カメラに自動巻き上げ 35 $\mathrm{mm}$ カメラ (C-35 AD-4), フィルムにコダックパナト ミックXを使用した。解析には，NEC 社製パーソナル コンピュータ PC-9801 型を使用し， 二次元座標値の入 力装置としてデジタイザー（Logitec K-510）を，出力 装置としてカラーデイスプレー (NEC PC-KD 851), $\mathrm{XY}$ プロッター(GRAPHTEC FP 5301), 日本語シリ アルプリンタ（NEC PC-PR 201）を接続した。 また解 析プログラムは，当教室において開発したものを使用し た.

\section{4. 実際の解析法}

1）写真上で，䎌胞内腔面に平行にX軸，これと直交 する方向にY軸を設定し，デジタイザーを用いてすべて の血管の断面の基底板上の 8 点の座䧣をX $\mathrm{X}$ プロッター で描記する（図 4).

2）薄切前後で，X軸方向，Y軸方向で計算した抎 大・縮小率をプログラムにインプットする.

3）補正した血管断面をX Y プロッター上の紙面に描 記する。

4）写真および 3）で描いた血管断面を参考にして, すべての血管を毛細血管，細動脈，小動脈，細静脈，小
静脈に分類する。

5 ）血管角度测定の対象として毛細血管，細動脈を選 び，その長径および短径の 4 点の座標をデジタイザーを 用いて入力し, 各血管の内腔面に対する 角度を計算す る。ただし，断面が円または棈円と極端に違うものは対 象外とした。 また細静脈，小静脈は円筒形の連続である と仮定できないのではじめから除外した。また小動脈に ついては細血管とはいえないため除外した。

6）算出された血管の角度のヒストグラムをXYプロ ッター上紙面に描記し，便宜的に㢣胞内腔面に対して $0^{\circ} \sim 45^{\circ}$ 末満の血管を水平型, $45^{\circ}$ 以上 $90^{\circ}$ 以下の血管 を縦型とした。

なお，1例につき 4 つの切片を作製し，それぞれ慗胞 壁を内腔側より外側にむけて 4 つの部分に分け，炎症性 細胞浸潤の程度により炎症を, なし (一), 軽度 (十), 中等度 (H), 高度 (H) の 4 段階に分類し, 部位別に 炎症の有無と血管の角度との関連性を検討した。

5. 統計処理の方法（有意差検定）

$\chi^{2}$ 検定および Wilcoxon 検定を用いた。

なお，ある棈円形の血管断面を32点で描記し補正した 後, 血管走行角度を計算する操作を20回繰り返し求めた 值に対し，8点で描記した場合の測定誤差は $2.9 \pm 0.1^{\circ}$ 以内であった。

\section{研 究 結 果}

\section{1. 各種襄胞の総血管数および種類別血管数}

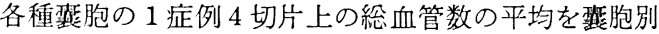
にみると，歯原性角化和胞が 174 個と最も多く，最低は 含菌性㷊胞の 114 個であった。 また，炎症性裂胞の平均 は168個と発有性慗胞の152個よりやや多かったが，両群 間には有意差は認められなかった。種類別血管数につい てみると総血管数のらち毛細血管の占める割合は平均 $68.8 \%(63.8 \sim 77.6 \%)$ といずれの整胞でも最も多く, 次いで細静脈の平均 $26.8 \%(18.4 \sim 34.9 \%)$ であった。 細動脈は平均 $2.3 \%(0.6 \sim 4.0 \%)$ ，小動脈は平均 $1.9 \%$ (0〜 2.9\%) で，小静脈は平均 $0.4 \%(0 \sim 0.7 \%)$ と最も 少なかった。

\section{2. 部位別の炎症出現頻度}

4つに区分した整胞壁に打ける炎症の出現頻度を切片 数で示したものでみると，炎症性砅胞では，すべての層 で炎症のあるものの方が多かった。 また，炎症のないも のは最内層では1つもなく，外晛に行くにしたがって多 くなり，近に炎症のあるものは最内層にいちばん多く外 側に向かって徐々に少なくなる傾向がみられた，一方， 発育性榀胞では，全体的には炎症のあるものとないもの はほぼ同じ割合で，最内層にも炎症のないものが認めら れた。含崡性榀胞では炎症のないものとあるものは，ど の層も泀注平均してみられたが，その他の榀胞では炎症 

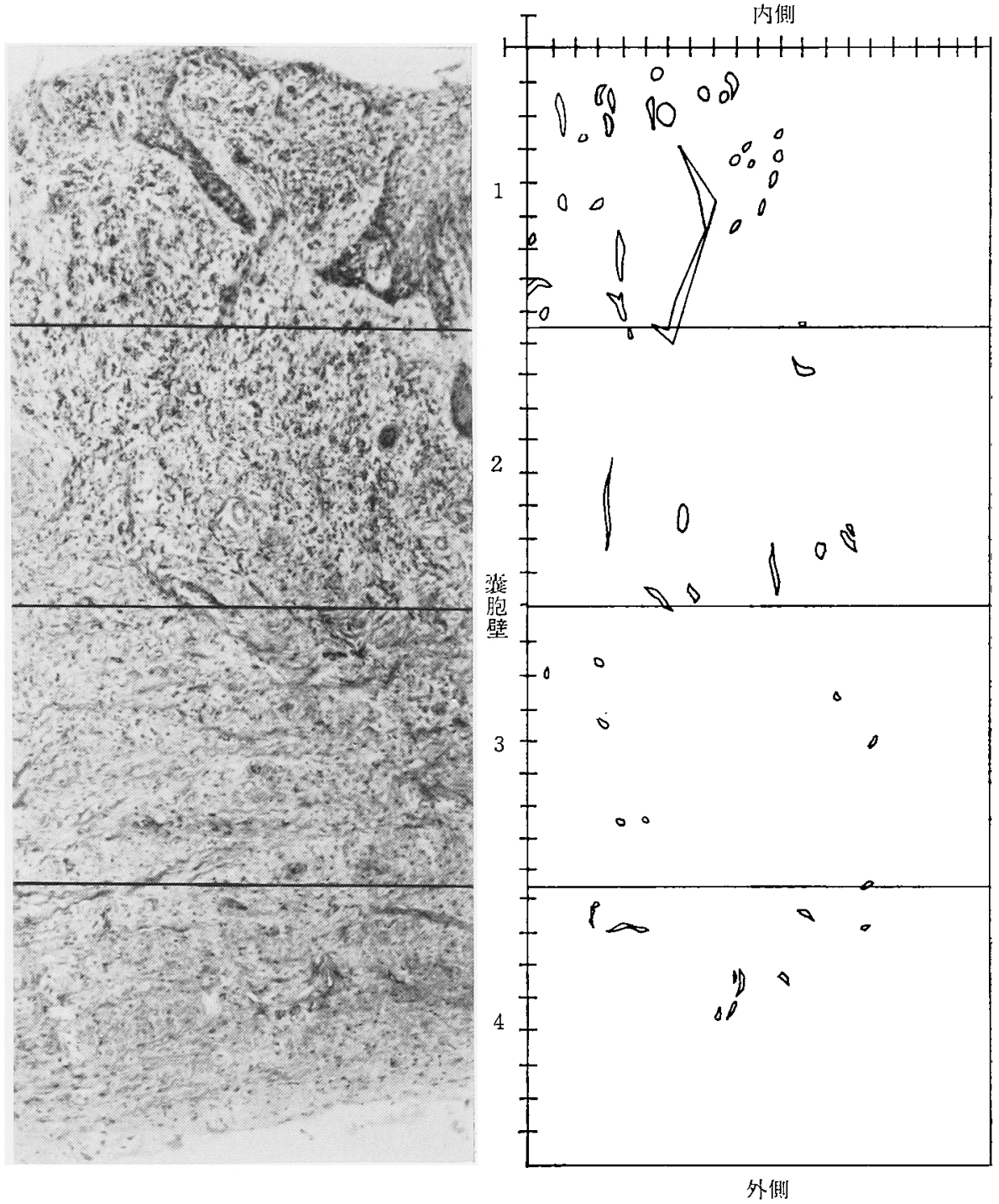

図 4 血管断面の描記

表 2 総血管数执よび種類別血管数（1例またり）

\begin{tabular}{|c|c|c|c|c|c|c|c|}
\hline & 歯根䔐胞 & 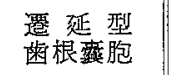 & 原始性薄胞 & 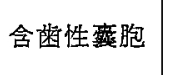 & 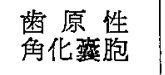 & $\begin{array}{l}\text { 㦼口蓋管 } \\
\text { 簬胞 }\end{array}$ & 平 均 \\
\hline 総血管数 & 173 & 163 & 172 & 114 & 174 & 147 & 157 \\
\hline 毛細血管数 & $123(71.1 \%)$ & $104(63.8 \%)$ & $111(64.5 \%)$ & $79(69.3 \%)$ & $116(66.7 \%)$ & $114(77.6 \%)$ & $108(68.8 \%)$ \\
\hline 稩 動 脈 数 & $4(2.3 \%)$ & $5(3.1 \%)$ & $1(0.6 \%)$ & $2(1.8 \%)$ & $7(4.0 \%)$ & $3(2.0 \%)$ & $4(2.3 \%)$ \\
\hline 小動脈 数 & $5(2.9 \%)$ & $4(2.5 \%)$ & $0\left(\begin{array}{ll}0 & \%\end{array}\right)$ & $2(1.8 \%)$ & $5(2.9 \%)$ & $2(1.4 \%)$ & $3(1.9 \%)$ \\
\hline 科静脈数 & $40(23.1 \%)$ & $49(30.1 \%)$ & $60(34.9 \%)$ & $31(27.2 \%)$ & $45(25.9 \%)$ & $27(18.4 \%)$ & $42(26.8 \%)$ \\
\hline 小静 眽 数 & $1(0.6 \%)$ & $1(0.6 \%)$ & $0\left(\begin{array}{ll}0 & \%\end{array}\right)$ & $0\left(\begin{array}{ll}0 & \%\end{array}\right)$ & $1(0.6 \%)$ & $1(0.7 \%)$ & $1(0.4 \%)$ \\
\hline
\end{tabular}


战根虽胞

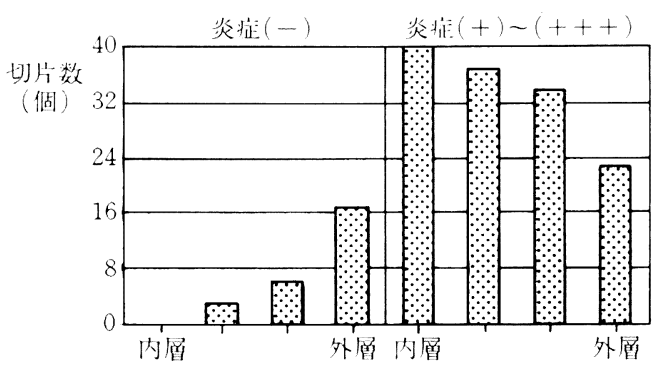

造延型苇根轱胞

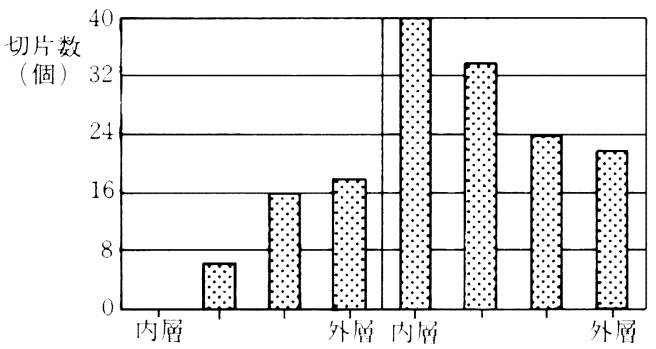

炎症性薮胞全体

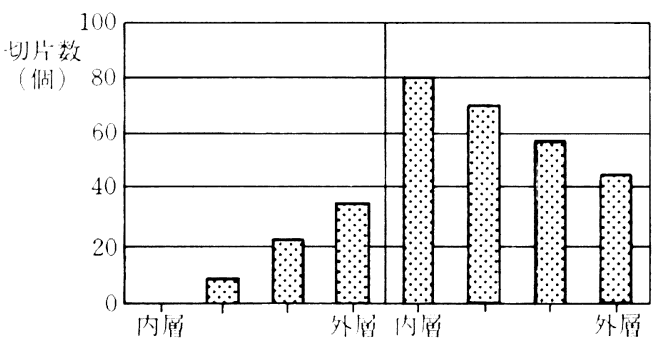

原始性孉胞

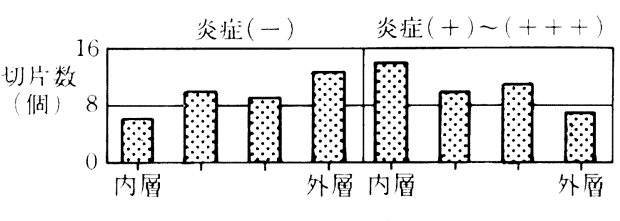

含㐘性獾胞

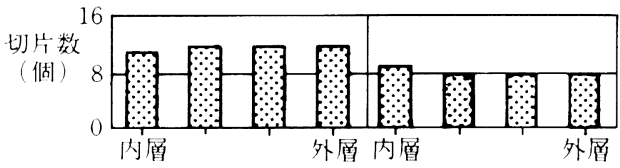

㐘原性角化蓯胞

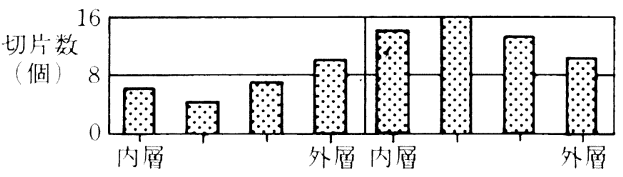

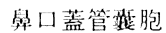
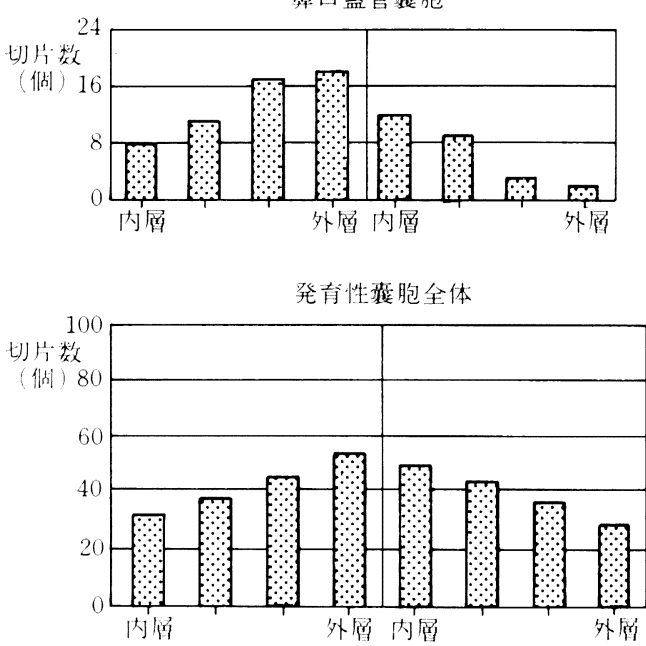

図 5 部位別の炎症出現頻度

性呞胞之同様, 炎症のないものは最外層に多く, 炎症の あるものは内層から外層に向かって減少する傾向がみら れた。しかし，その傾向は炎症性孁胞より弱いようであ った（図５）.

\section{3. 炎症別・部位別総血管数}

炎症のあるものとないものについて部位別の 1 切片あ たりの総血管数の平均をみると, 炎症性楚胞, 発肓性整 胞のいずれも炎症のあるものでは, 部位別の血管数の違 いは認められなかった。一方, 炎症のない発育性婯胞で は内側 2 層の方が外側 2 層より血管数は有意に（危険率 1\%)多くなっていた。 しかし, 炎症性雚胞では, その よらな傾向はみられるものの統計的有意差はなかった。 なお, 炎症の有無で比較すると, 両群とも注とんどの層
で炎症のあるものの方が血管数は有意に（危険率 5\%) 多くなっており，その主体は毛細血管であった。たた し, 炎症性鸪胞群では最内層に炎症のない切片はなかっ たので，分析に含めていない（図６）。また，炎症性簧 胞群と発育性整胞群で比較すると一層あたりの血管数の 平均は，それぞれ炎症のないものでは7.7個と7.5個，炎 症のあるものでは11.2個と11.6個と両群間に統計的な有 意差はみられなかった（図 7).

\section{4. 各襄胞の血管走行について}

各種捛胞の 1 例あたりの走行角度計測の対象となった 毛細血管および細動脈の合計数, 除外数, 分析血管数の 平均についてみると, 各垶胞 1 例あたりの除外血管数は 8〜24個（8.5〜18.9\%）で，結局分析できた血管数は， 
表 3 対解血管数・除外率および分析血管数（1例古たり）

\begin{tabular}{|c|c|c|c|c|c|c|c|}
\hline & 料根蒛胞 & $\begin{array}{l}\text { 邆 延 型 } \\
\text { 菓根整胞 }\end{array}$ & 原始性藻胞 & 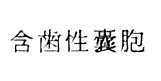 & 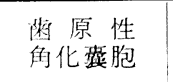 & $\begin{array}{l}\text { 奥口蓝管 } \\
\text { 慗胞 }\end{array}$ & 平均 \\
\hline 対像血管数 & 127 & 109 & 112 & 81 & 123 & 117 & 112 \\
\hline 除外数 (除外率) & $24(18.9 \%)$ & $14(12.8 \%)$ & $20(17.9 \%)$ & $8(9.9 \%)$ & $13(10.6 \%)$ & $10(8.5 \%)$ & $15(13.1 \%)$ \\
\hline 分析血管数 & $103(81.1 \%)$ & $95(87.2 \%)$ & $92(82.1 \%)$ & $73(90.1 \%)$ & $110(89.4 \%)$ & $107(91.5 \%)$ & $97(86.6 \%)$ \\
\hline
\end{tabular}

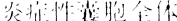

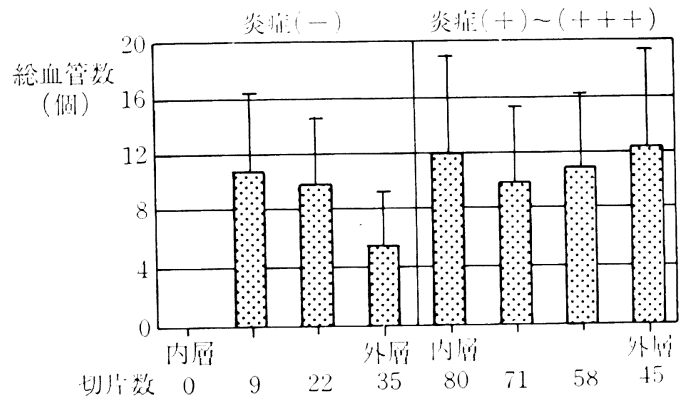

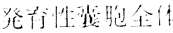

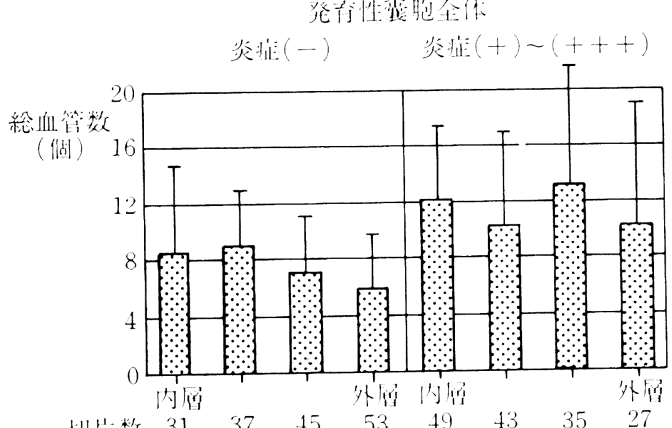

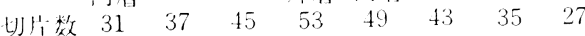

図 6 炎症別・部位別総血管数

最高が歯原性角化裂胞の 110 個, 最低は含米性霡胞の 73 個で平均は97個（86.6\%）であった（表了）。

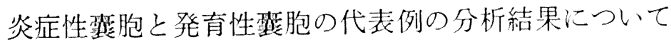
みると，歯根獘胞で最内層に著明な炎症があるものでは 粉型血管が王倒的に多く，一方，原始性䔶胞で最内層に 炎症のないものでは血管はすべて水平型であった（図 $8)$.

炎症性露胞の縦型・水平型血管の割合を全体, 炎症の あるもの，炎症のないものに分けてみると（なお，分 析血管数が 20 以下のものは除外した）炎症のあるもの では, 両裂胞とも最内層は縦型, 最外層は水平型が倎位 となる傾向があり，歯根整胞，嗘延型㐘根露胞の内側 2 層の縦型血管の割合はそれぞれ，57.8\%，60.8\%であっ た。

一方，発生の発端となった炎症がなくなったもので

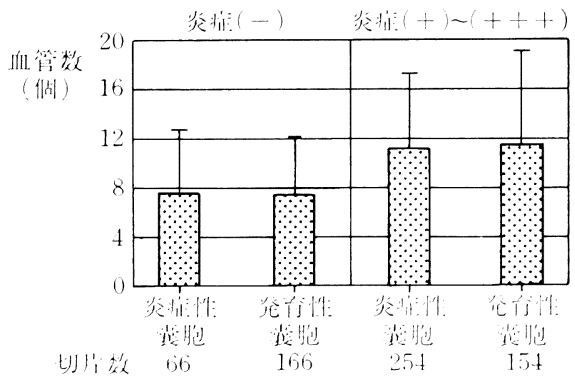

図 71 切片 1 層古たりの血管数

は, 、ずれの層も水平型が多く, その傾向は遥延型歯根 䁚胞の方が著明であった。また，外層活ど水平型が多く なる傾向がみられ，最外層の又に注目すると，いずれの 罩胞でも水平型が主体であった。

全体でみると，歯根整胞と遷延型歯根露胞では，縦型 血管が最内層から最外層にいくにしたがって，それぞれ $57.1 \%$ から $26.2 \% ， 60 \%$ から $36.1 \%$ 一と減少して打り， 最内層は橡型, 最外層は水平型が優位であった（図 9 ).

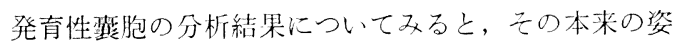
を示していると思われる炎症のないものでは，原始性露 胞の一部を除いてすべての部位で水平型が主体で $61.9 \%$ から $82.6 \%$ を占めていた。

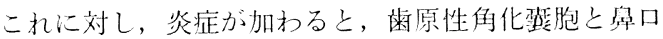
蓋管罴胞では縦型血管が增えていたが，原始性箦胞と含 歯性傕胞ではそのような傾向はあきらかでなかった。 た最内層だけをみると寸べての藏胞で水平型が䚄位であ

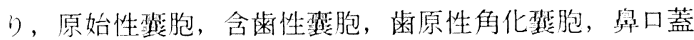
管省胞の内側 2 層に拈汁る水平型血管の割合は，それぞ れ63.3\%，56.6\%，55.7\%，52.6\%であった。最外層に

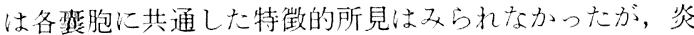

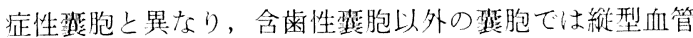
が優位となっていた。

全体としては, 発育性雚胞のすべての部位で水平型が 㦝位であった（図10）。

さらに最内層の糈型，水平型血管の割合を炎症がない かごく軽度なものと非常に高度なものに分けてみると， 高度の炎症がある場合には，炎症性整胞では桁型が主 体，発育性雚胞では綎型血管が增えているものの依然水 

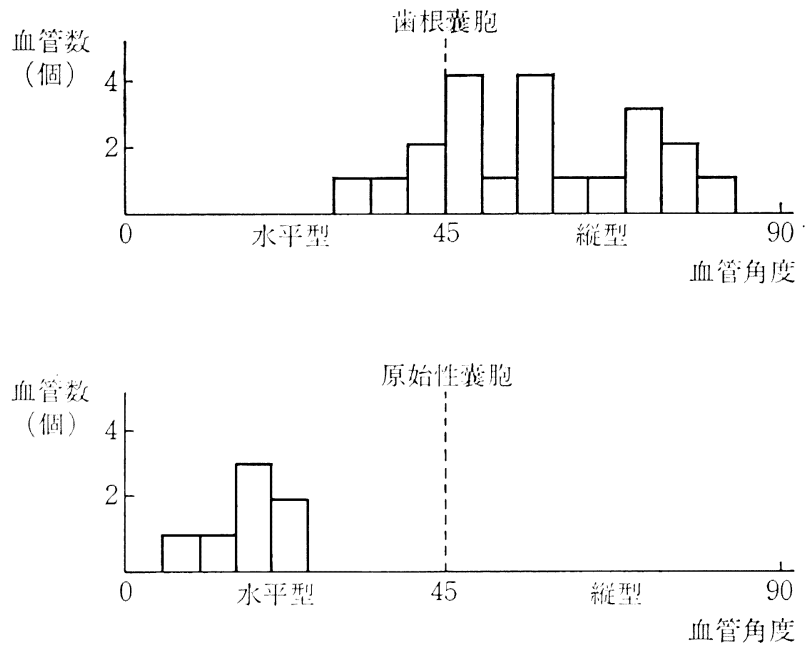

図 8 角度別血管個数のヒストグラ
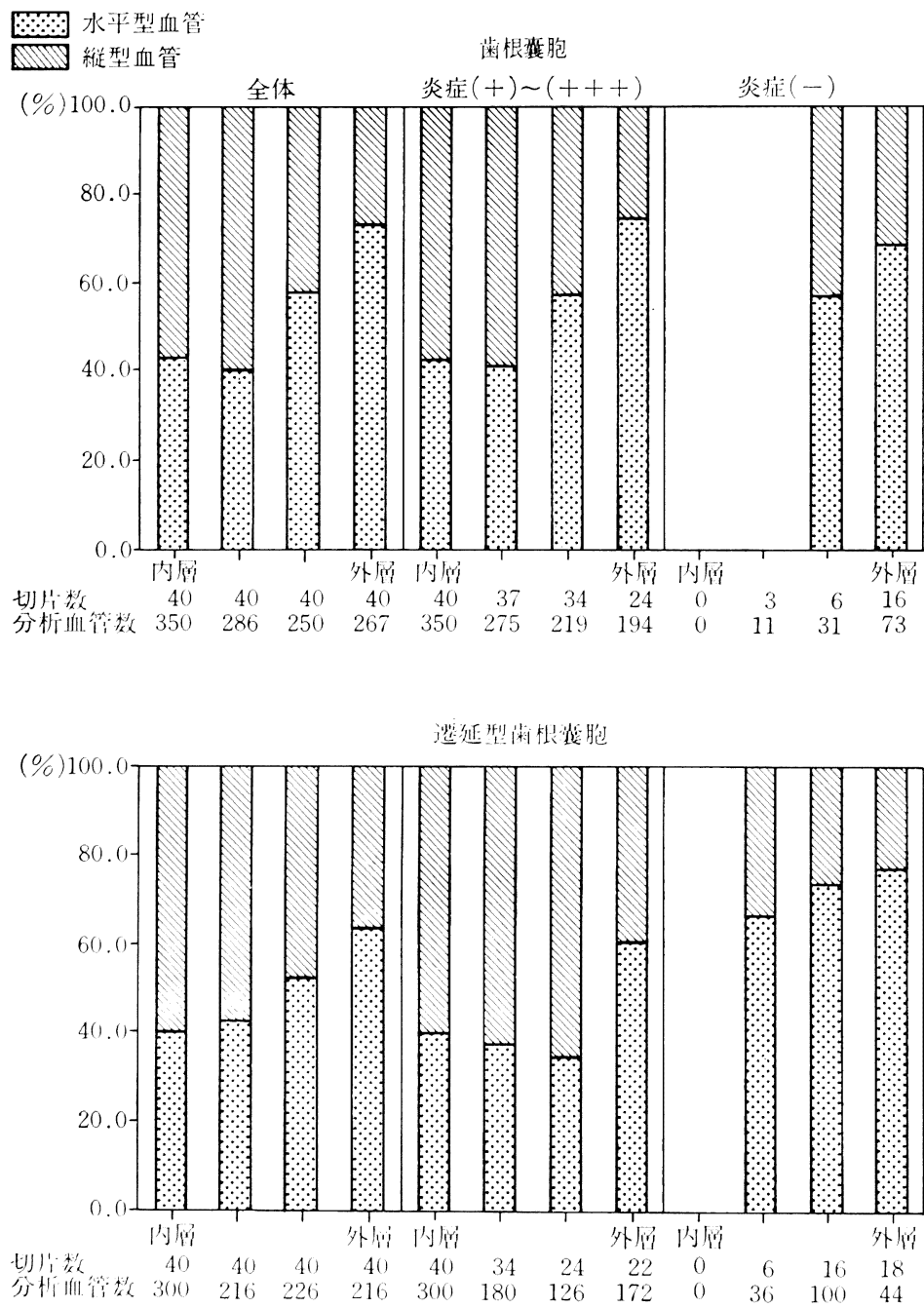

図 9 炎症性浇胞の縦型・水平型 血管の割合 


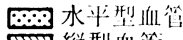
而縦型血管:

(\%) 100

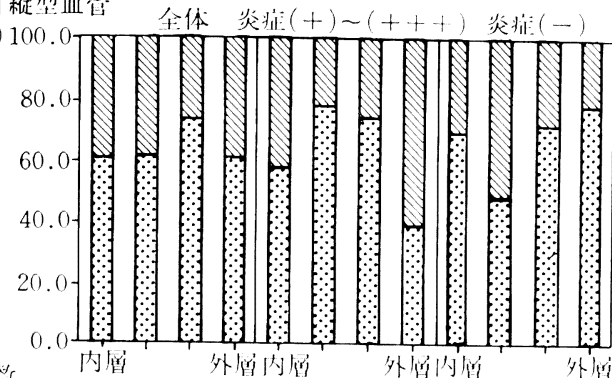

切片楼

外居内展

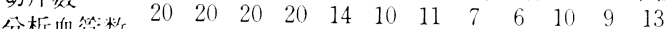

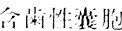

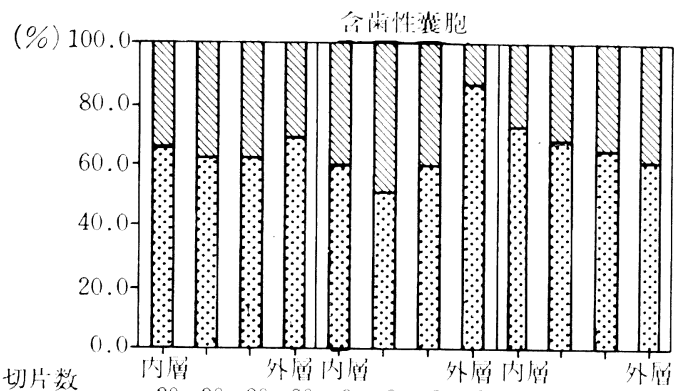

分析血管: $\begin{array}{rlllllllllll}20 & 20 & 20 & 20 & 9 & 8 & 8 & 8 & 11 & 12 & 12 & 12\end{array}$

分析血管数 $\begin{array}{rrrrrrrrrrrr}124 & 106 & 77 & 58 & 65 & 41 & 51 & 16 & 59 & 65 & 26 & 42\end{array}$

$(\%) 100$

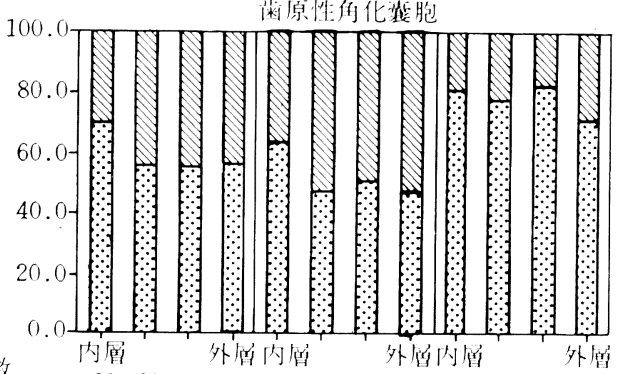

划片数

外居们店

外尾内用

外屏

分析血管数 $\begin{array}{rrrrrrrrrrrr}20 & 20 & 20 & 20 & 14 & 16 & 13 & 10 & 6 & 4 & 7 & 10\end{array}$

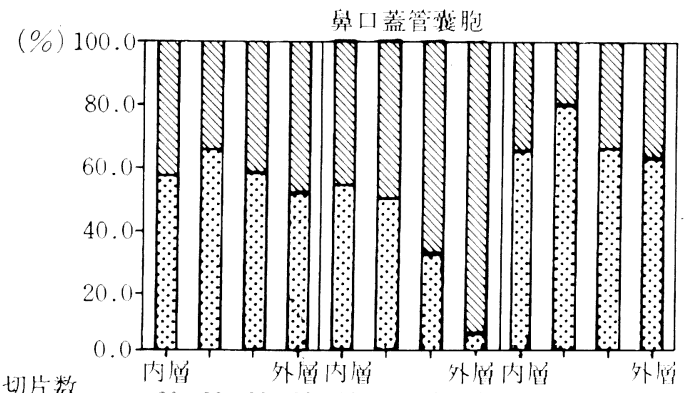
$\begin{array}{lrrrrrrrrrrrr}\text { 分析血管数 } & 20 & 20 & 20 & 20 & 12 & 9 & 3 & 2 & 8 & 11 & 17 & 18 \\ 158 & 155 & 135 & 87 & 118 & 78 & 32 & 17 & 40 & 77 & 103 & 70\end{array}$

図 10 発省性戞胞の維型・水平型血管の㓶合
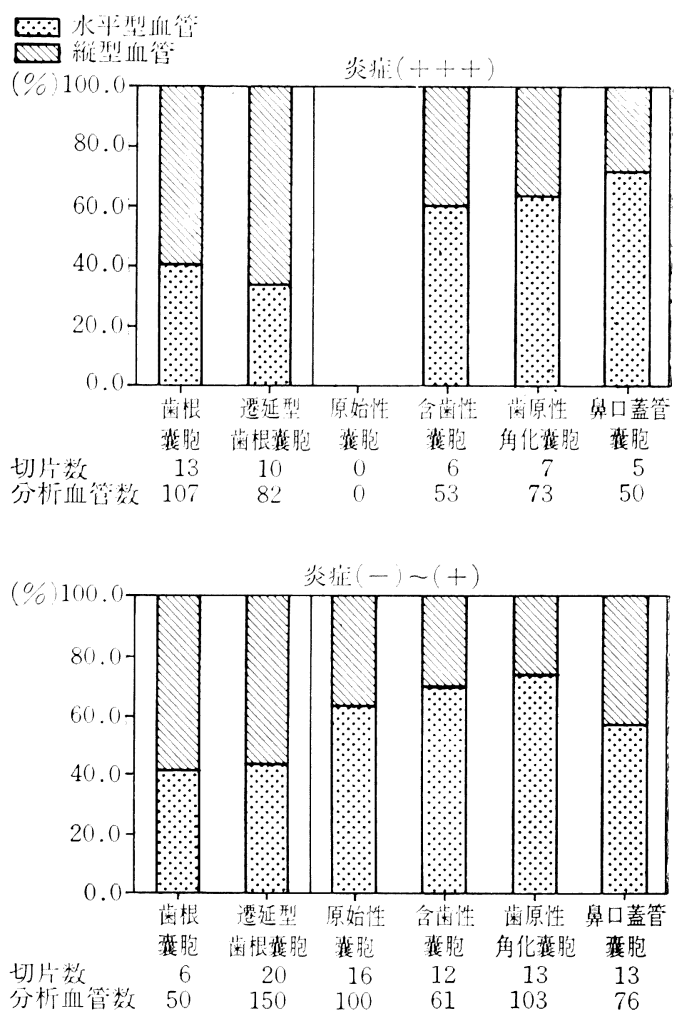

図 11 最内層の縱型・水平型血管の割合

平型が主体で，綎型血管の割合は炎症性型胞の方が発育 性露胞に比して有意に（危除率５％）高かった。

一方，炎症がないかごく軽度のものでは，発育性雖胞 では我平型が優位であるが，炎症性裂胞では依然縦型が 優位で, 水平型血管の割合は発育性嘿胞の方が有意に （危除率 1％）高加た（図11）.

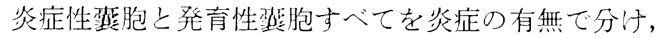
部位別に樅型・水平型血管の占める割合を久ると, 炎症 性雚胞, 発育性雚胞ともに炎症があるとあきらかに絽型 が增加する傾向がみら机たが，炎症性裂胞では最外層の 次の層以外には炎症のあるものとないものの間に統計的 有意差は認められず，炎症がなくなってもまだかなり縦 型血管が残っていると考兄られた，一方，発青性独胞で は縦型血管の割合はすべての層で炎症のあるものの方 がないものに比して有意に（危険率 $1 \%$ ）高くなって おり, 炎症が加わると本来の水平型血管に加えて, 㬵型 血管が急に增えることが示された。しかし，炎症性罣胞 と発育性整胞を内側 2 層のみで比較すると, 綎型血管の 割合は炎症のあるものでも前者の方が有意に（危除率 1 \%) 高く，また水平型血管の割合は炎症がなくなったも のでも後者の方が有意に（危険率 $5 \%$ ）高かった（図 12). 

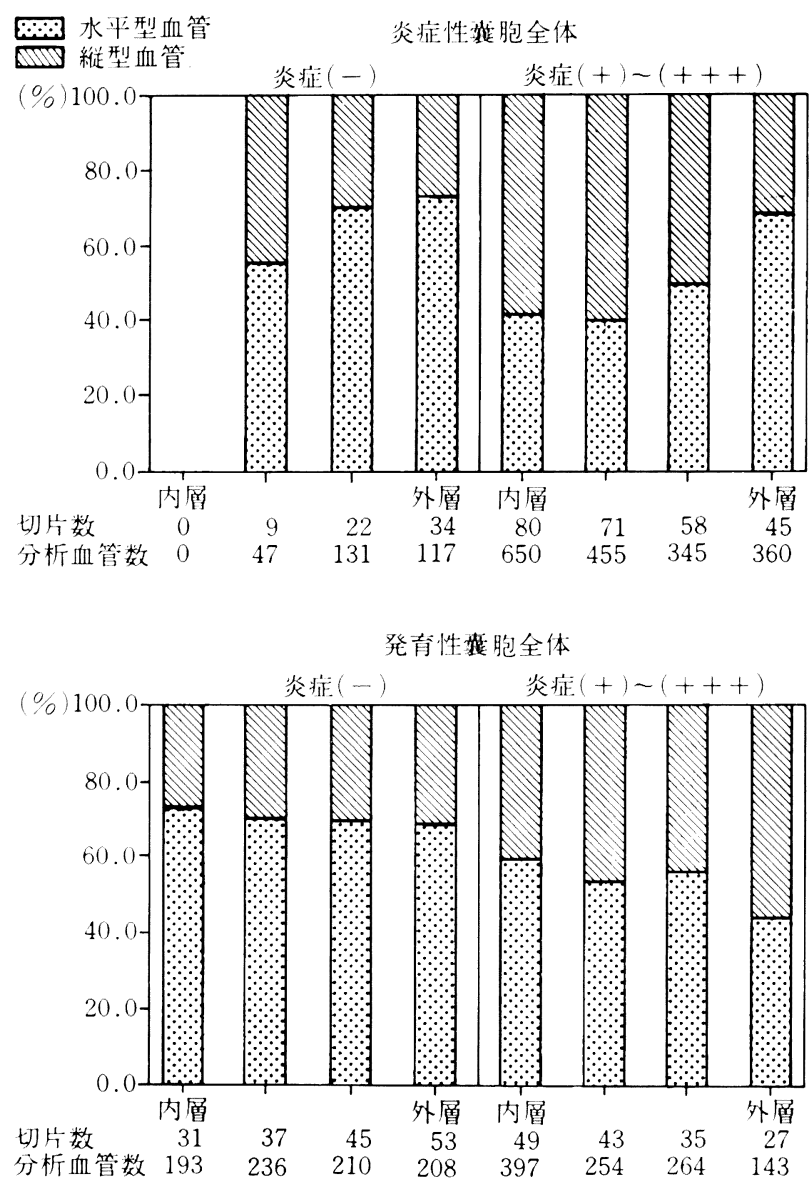

図 12 炎症の有無別・縦型水平型血管の制合

\section{考察}

\section{1. 血管走行状態の検索方法について}

ヒトや動物の各種臓器の血管走行状態を娭索する方法 としては, 樹脂注入による鋳型法 ${ }^{7 \sim 15)}$, 化学的消化法 ${ }^{15 \sim}$ 18), 連続切片による再挜築法 ${ }^{1923)}$, 色素注入㣪透明摽本 として観察する方法 ${ }^{13)}$, 造影剂注入によるX線像による 方法乩などがある。

樹脂注入による鋳型走查電子顕微鏡法は, 動脈系より メチルメタクリレートなどの樹脂を注入して, 得られた 鋳型を観察する方法である。現在までにこの方法によ

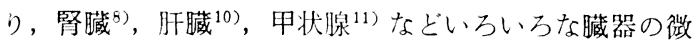
小血管の分布，連絡が三次元的にあきらかにされてき た。しかしながら、ヒトから摘出した靧骨掏胞には樹脂 を注入できるような太い血管がないため，この方法を用 いることは不可能である。
化学的消化法のうち，1976年に Evan ら ${ }^{17)}$ が開発し た塩酸コラゲナーゼ法は，固定試料に塩酸処理・コラゲ ナーゼ処理を行うことにより，結合組織成分および基底 膜を消化し血管内皮細胞の基底面を観察しようとする方 法て, サルの甲状腺 ${ }^{15)}$, ラットの頱下腺などの毛細血管 絪 ${ }^{15)}$ ， ラッ卜の舌下腺の平滑筋上皮 ${ }^{16)}$ ， ウサギの硝子体 内網膜毛細血管18)などの分析に応用されている。この方 法は、これまではコラーゲンや基底膜の存在のために困 難であった絊胞基底面の走查電顕の観察を可能にした画 期的方法といえるが，結合組織線維成分の多寡によって 成績が著しく左右される。比較的安定性に乏しく同一組 織または陚料において子常に同じ結果が得られるとは限 らない, 試料表面に消化処理に伴らコンタミネーション がつきやすくきれいな写真が得られない，塩酸やコラゲ ナーゼ処理による紐胞の収縮, 小孔などの人工産物が出 現するなどの問題点がある ${ }^{18)}$ 藷者も塩酸コラゲナーゼ 法を夷際に顎骨褧胞に応用してみたが，露胞壁の結合組 
織が消化されずに残ったり，血管そのものが溶解してし まうことが多かった。 よってこの方法は，顎骨裂胞壁の 血管走行状態を検索するのには不適当と思われた。

連続切片による再構築法は, 病理学分野で細胞や組織 の立体棈造の把握のために ${ }^{19)}$, また神経解剖学や器官発 生学を中心に形態学的研究に広く用いられてきた ${ }^{22)}$, 再 構築法には，適当な大きさに拡大された写真を紙あるい はガラス板に写し取り，順次重㸚あわせて複满するトレ ーシング法と，撮影された写真を抁大率に応じた口ウ板 や厚媇，あるいはプラスチック板に写し取って切り抜 き, これを順番に重权合わせ複满する層板複棈法があ る19,22) 本法により得られる情報量は非常に大きく素晴 らしいものであるが，実際には大変な労力と時間を要す る仕事であり，技術的にも高度の完全性を要求される。 よって細い血管の存在する翼胞壁の血管走行状態を梌索 するのには，不向きであると考光られた，

また色素注入後透明標本として観察する方法, 造影剂 注入によるX線像による方法化ついても，注入できるよ うな太い血管がないので不可能であった。このように今 まで用いられている方法は，いずれも顎骨跡胞壁の血管 走行状態を検索するのにはらさわしくないと考えられ 垊。

そこで新しく㡀胞壁の病理切片での血管の断面より站 胞内腔面に対する血管の走行角度を求める方法を考案し 実際に応用してみたが，この方法を用いる上でいくつか の問題点があげられる。

第 1 に，すべての血管は必ずしも円筒形の連続である とは限らないということである。

弾性型の動脈は, 中膜に弾性線維が多く, 大きい弾性 を有しており，また筋型の動脈は内膜，中膜，外膜の区 別が明瞭で中膜の平滑筋層がよく発達して厚く, 筋線維 の間に弾性線維が比較的少ない24 26). 小動脈は, 細動脈 につづく部分で内膜には内皮細胞と内弾性板, 中膜には 2 数層の輪走平滑筇, 外膜には外弹性板と結合組織を もっている ${ }^{24 \sim 26)}$. 細動脈は毛細血管に移行する直前の直 径 10〜15 $\mu \mathrm{m}$ 程度の細い動脈で, 内皮細胞とその回りを 輪状に取り巻く平滑筇細胞からなる ${ }^{24 ~ 26)}$ 。これらの動脈 の血氏 は大動脈基部で $100 \mathrm{mmHg}$, 小動脈部で 60 90

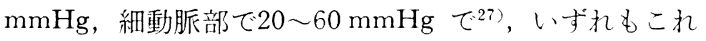
らの压に十分耐兄られるよらにできている。

毛細血管は直径 $5 \sim 10 \mu \mathrm{m}$ の最も細い血管で，その壁

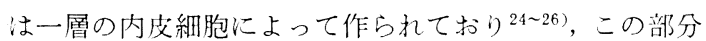
での血压は，10〜30 mmHg である24,27). Elias \& Pauly ${ }^{25}$ は毛細血管をすべて円柱に描いている。

一方, 静脈についてみると, 太い静脈では中膜の発育 がきわめて微弱であるが，中等大の静脈は内膜・中膜 外膜の 3 層よりなり構造は変化に富む ${ }^{24 ~ 26)}$. 小静脈は輪 走する平滑筋が間断なくならび 3 層が区別できるが，中 膜の平滑䇗線維は小動脈に比して数も少なく配列も疎て

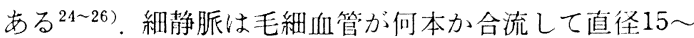
$30 \mu \mathrm{m}$ になったもので，内皮細胞，銀好性線維網，輪走 する平滑笳線維よりなるが，平滑筋の配列は紐動脈に比 べるとかなり不規則ではなはだ柾である24 26) また静脈 の血里は10 mmHg ないしそれ以下である27) Bloom \& Fawcett ${ }^{28)}$ は，切片でみると静脈は一般につぶれた状態 にあり，静脈腔は固定に際して特別に膨れるようにしな いと不規則な隙間のように見えると述べ，また山本 ${ }^{299}$ は，固定摽本では動脈が注注円筒状に保たれているのに 対し、静脈はしばしば不規則に恋形してみえると記述し ている.

このようにみてくると, 細静脈, 小静脈なとは円筒形 であるとはいえないが，小動脈，細動脈，毛細血管は血 管壁の構造および内王などより考えて，注汴円筒形の連 続であると仮定してょいと思われる。そこで本研究では 細動脈，毛紐血管の久を血管角度测定の対象とした。

第 2 は，たとえ血管が円筒形の連続だとしても複雑な 網目を作っているから，断面は必ずしも円または棈円と はならないといらことである。そこで血管の分岐部など に相当すると思われる円または棈円とは形の違ったもの については計算から除外することにした。計算より除外 した毛細血管，細動脈の割合は平均で13.1\%であった。

なお，塩酸コラゲナーゼ法にて得られた歯根型胞壁の 血管の走查電顕像より $5 \mu \mathrm{m}$ の切片を作ったとした場 合，分岐部泪当する血管の割合は $13 \%$ であり，本研究 での実際の除外率に一致していた。

第 3 に，血管の断面の四点を，とこを基準にしてとっ たらいいかといら問題である。血管によっては収縮して いて内腔が認められない場合もあり，内腔を基準にはで きない. Bloom \& Fawcett ${ }^{29}$ は、，管腔の開いた小動脈と 血管収樎を起こした小動脈を比較すると, 血管壁の構造 が著しく変化していると述べている。しかし，彼の論文 で示した図では内腔の变化に比べて基底板の変化は比較 的少ないことがわかる。 そこで内皮細胞の外側で形態変 化の少ない基底板を基準にすることにした。

第 4 亿，血管の断面像を得るまでの過程における変形 の問題である。山崎ら ${ }^{20}$ は, 形態計測時の配虑のポイン 卜として, 固定, 脱水系列, 包埋操作, 印画紙一の罕真 の焼付计, 切片作成時の薄切力向への王樎, 顕微鏡のレ

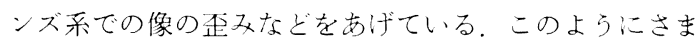
ざまな過程で変形を生ずる可能性があるが，特に薄切の 際の王穛による変形はかなり大きいので，各切片ごとに $\mathrm{X}$ 軸, Y軸での縮小率, 抁大率を計算し, プログラムに 組み入れることにより变形を修正した。

最後に, 測定䛊差の問題がある。しかし, 血管の走行 角度の測定誤差は $2.9 \pm 0.1^{\circ}$ 以内であり, 汪とんど問題 にならないと思われた。

このように多少の欠点はあるものの，この方法は㢣胞 壁の血管走行状態を検索する上で有用であると思われ 
た.

\section{2. 震胞の血管数と炎症との関係について}

各種琶胞の総血管数は炎症性落胞の方が多かったが, 発育性聚胞との間に有意差は認められなかった。

また，種類別血管数については，全体では毛細血管が $68.8 \%$, 紐静脈が $26.8 \%$ で, 炎症性整胞, 発育性露胞い ずれも裂胞壁の血管は、、とんどが毛細血管と紐静脈で 占められていた。

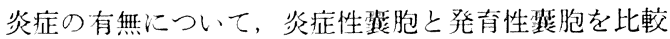
すると，前者は炎症のあるものがないものに比べてあき らかに多く，後者は炎症のあるものとないものの割合は ほぼ同じであった，炎症性霆胞は炎症に起因したものな

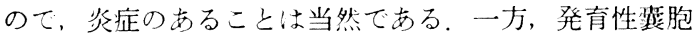
は炎症がない状態が基本であると考えられるが，今回の 症例では炎症の既往のあるもの，または初診時炎症症状 のあるものは 40〜100\%を占めており，感染がその発見 や治療のきっかけになっていたため、このような結果に なったのであろう。

次に, 部位別の炎症出現頻度について, 炎症性蓝胞と 発育性篮胞を比較すると, 前者では炎症のないものは最 内層にはなく，後者では炎症のないものも最内層にみら れたといら違い以外は, 炎症のないものは外層に行くに したがって多くなり，逆に炎症のあるものは最内層にい ちばん多く，外側に向かって徐々に少なくなる傾向が両 群ともに認められた。炎症性裂胞は根尖部を雚胞内腔に 含んでいることより炎症は内腔面から外側に向けて波及 するものが多く, 内側ほど炎症出現頻度が高いのは当然 である。一方，発育性秚胞では感染源は裂胞腔内にはな く，はじめは外から炎症が波及してくるが，一度感染し て炎症を起こすと，抗生物質の投与を行っても内腔は血 行がなく死腔と同じため感染が消去できず, 細菌が生有 して残りやすいとされている30). そのため内層は治りに くく慢性炎として残るため, 炎症性型胞之同様の所見に なったと考えられる。たた，感染源が碳胞腔内にあり絶 えずそこからの炎症性刺激が加わっていたと考光られる 炎症性蕗胞汇比較すると, 内層汪ど炎症のあるものの頻

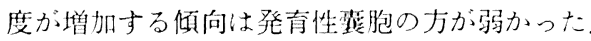

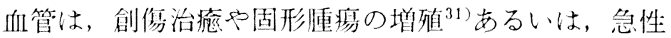
㻏出期炎症求上び慢性增殖型炎症 ${ }^{32}$ などの際に活発に新 生するといわれている。

鉿江・小林ら ${ }^{33}$ は，血管新生には血流の存在と陴害さ れた組織に由来与る何らかの刺激が必要であると述べ，

Clark \& Clark $^{31}$ も新生血管の成長は，活発な循環およ び炎症性の没出物の存在のもとで最も早く生じると述べ ている。佐藤ら ${ }^{35}$ 怙, この上らな因子が筋線維芽細胞汇

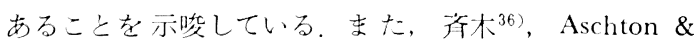
$\mathrm{Cook}^{37}$, 吉塚 ${ }^{37)}$, 星子 ${ }^{35)}, \mathrm{Cogan}^{39}{ }^{39}$ 友とは, 血管新生の 条件として浮腫および血管伸展の場が得られる程度の固 有質䧸密性の低下をあげている。しかし，その新生機序
については，いまだに血管は血管内皮細胞から新生する といら説と末分化間葉細胞が関与するといら説に分か水 ており，またその際に作用するとされている血管造成因 子についても，不明な点が少なくない,31,35)。しかし，炎 症によってもたらされる環境の生化学的変化（高浸透 王, アンドーシス, 電解質の変化など) や局所の組織か ら遊滩される化学的物質 ${ }^{33)}$ が血管新生を促すことは間違 いない上うである。本研究の症例でも炎症の有無と血管 数の関係をみると，どの嫼胞でもほとんどすべての部位 で炎症がないものに比べ, 炎症のあるものの方が総血 管数, とくに毛細血管数が增加しており, 炎症による環 境の変化が血管新生と深い関係をもっていることが示咬 された。

\section{3. 各震胞の血管走行について}

走行角度計測の対象血管数, 除外数, 分析血管数之も に炎症性郦胞之発育性裂胞之の間に有意差は認められ ず，い寸゙れの篮胞においても炎症があると縦型血管の增 加する傾向がみられた。ではなぜ炎症があると綎型が多 くなるのであろらか.

信藤ら ${ }^{40}$ はイ又の歯肉の創傷において, 創中央に向か って毛細血管は伸展していくのを観察しており，三方 $5^{411}$ もラットの背部皮㲊創部で，增生血管は初期汇特 別の方向性を示さないが，第 4,5 日頃には皮鬳表面に 対して直角方向，寸なわち創底部より表面への走行が目 だつと記載している。同様な結果は，ウサギの皮㲊 ${ }^{36)}$, ダイコクネズミの角膜 ${ }^{37)}$ ，ラットの挙睪筋の創部 ${ }^{42}$ でも 観察されており，創傢治瘾においては，血管新生は創の 方向に向かって伸展していくことがわかる。

そこで鞾狍壁の血管走行についてみると，炎症のある 炎症性裂胞では最内層は縦型血管が優位であり，最外層 は水平型が主体であった。このような琵胞では創傷治㵠 の場合と同様に，楧成血管の主体となっている毛細血管 は外層から炎症の最も起こしやすい最内層に向かって伸 展していったものと思われる。したがって, 最内層汇緃 型血管が多くなったのは当然のことであるう。

ではなぜ最外層は水平型血管が主体となったのである らか。斉木 ${ }^{36}$ ( 2 組織由来の間葉系幼若線維芽細胞の一部 は, 成熟線維芽細胞へと分化しながら細胞周辺に膠原線 維の形成を行い, 肉芽組織の線維化を行うと述べてい る，通常，粀根整胞に打いては炎症のおさまりやすい部 位，すなわち最外層では線維化が進んでおり，その線維 の方向は内腔面に対して平行になっている，Ross ${ }^{31)}$ ，鉿 江, 小林 $5^{33}$, Schocf $5^{43}$ は肉第組織の線維化が進行寸 ると毛紐血管の一部は細動脈・紐静脈に分化し，毛細血 管の大部分は炎症の経過とともに新生したと逆の過程で 消失すると述べている。しかし，炎症が存在する場合に は，毛練任管の一部は消失しないで残存し，それらが内 腔面に刘して平行に走る膠原線維束の間隙に残ったもの と思われる。また，斉木 ${ }^{36)},\left(\right.$ Cogan ${ }^{39)}$, Schoefl ら ${ }^{43)}$ は 
新生血管は必ず組織抵抗の少ないところ，すなわち膠原 線維束の間隙を伸展すると述べている。したがって，最 外撔では新生した毛細血管もその多くは水平型血管とな るのであろう。

雚胞壁の炎症が消失し線維化が進めば，このような傾 向はさらに進み，その結果水平型血管の割合は高くなる

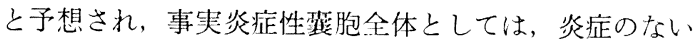
ものの方が炎症のあるものより水平型血管の割合は增え ていたまた，炎症性装胞でも長期間経過したと考えら れる要延型霜根筷胞では, 炎症のないものの水平型血管 は炎症のあるものより増加しており, 歯根琵胞の炎症の ないものと比較してもその割合は高くなっていた。しか し, 來根郦胞で炎症のあるものとないものを比較すると 両者間に外 2 層の水平型血管の割合の差はみられなかっ

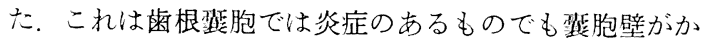
なり厚くなっており, 外層は線維化の進んでいるものが 多かったためであろう。なお，炎症性阆胞で最内層に炎 症が完全になくなっていたものはなかったので，その血 管走行については検討できなかった。

一方, 発青性䅽胞についてみると, 炎症の存在しない 場合には，ほとんどすべての層で水平型が主体であっ た。発育性変胞壁は一般的には裏層上皮と線維性結合組 織よりなり 2,4,44), 感染がなければ肉芽組織は認められな い. 線維性結合組織の膠原線維の走行は常に程胞内腔面 に対してほぼ平行で同心円状であり，路胞内腔面に対し て垂直に配列する例を著者は今までにみたことがない， よって発育性裂胞の基本となる血管走行はすべての層で 露胞内腔面に対して水平に走るものが多いということに なる。

次に発育性虽胞に炎症が加わったものをみると, 全体 としては炎症のないものより縦型は增加していた。しか

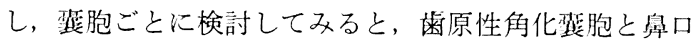

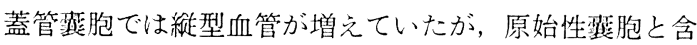
歯性整胞ではそのよらな傾向はみられなかった。これは 炎症性覇胞がはじめから炎症性刺激を受けて発生し，長 期間かけて増大していたのに比し，発育性蓝胞では炎症 は二次的なものであり，しかも炎症により発見されると 比較的短期間の5ちに治療を受けていること, 炎症刺激 により新生される血管はもともと内腔に平行に走る膠原 楾維のあるなかで伸展していること, さらに感染性胞胞 の外からもたらされることなどの理由によるものである 5 事实, 炎症の加わった発育性整胞では最外層の縦型 血管の増えているものが多く，含齿性露胞以外の玨胞で は縦型の方が優位であった。この点, 最外層では炎症の 有無にかかわらず水平型が優位である炎症性䔶胞と異な っていた。

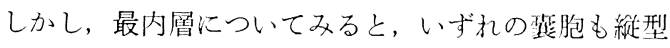
が增えているとはいえ，水平型が僋位であった。

また，最内層に炎症のない炎症性聇胞はなかったの
で，最内層に炎症がないか，ごく軽度のものと炎症が高 度なものに分けて検討してみると，炎症性踏胞では炎 症が鎮静化してきても依然颣型血管が優位であるのに対 し, 発有性整胞では炎症が高度になっても水平型血管が 主体であった。

このように炎症性整胞では最内層に炎症のないものは なく，その血管走行は基本的には最内層は幑型，最外層 は水平型で, 炎症が鎮静化すると最内層では水平型の割 合は增えるが依然として縦型が優位であるのに対し，発 育性琵胞では，炎症のないのが基本で，血管走行はとの 部位でも水平型であり，炎症が加わると最内層では緥型 の割合が増加するものの水平型の倲位は保たれている が, 最外層では縦型が主体となる傾向があるなどの相違 点がみられた。

よって, 湿胞壁の血管走行の分析は炎症性損胞と発育 性梪胞の鑑別䛦断の一助になるものと考えられた。

\section{結語}

病理組織切片上の血管の断面から血管の走行角度を求 める方法を開発し，これを用いて歯根琵胞10例, 遷延型

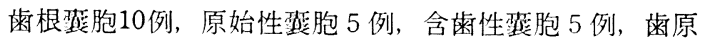
性角化雚胞 5 例, 鼻口蓋管露胞 5 例の栾胞壁の血管走行 について検討し，以下の結論を得た。

1. 雚胞壁の搆成血管は, 平均すると毛細血管が 68.8 $\%$, 細静脈が $26.8 \%$ と両者で大部分を占め, その分布に は炎症性蓝胞と発育性䔶胞の間には有意差は又られなか った。

2. 部位別の炎症出現頻度についてみると，炎症性賈 胞, 発育性賀胞いずれも最内層が最も高く, 外層に行く にしたがって低下していたが，炎症性莤胞ではその傾向 が著明で，最内層に炎症のないものは一つもなかった。

3. 炎症々血管数の関倸についてみると, 炎症性留胞 と発育性蓝胞のいずれも炎症により主として毛細血管が ほぼ同程度に増加しており，炎症のあるものでは部位別 の血管数の違いはみられなかった。一方，炎症のない発 育性霆胞では内層の方が外層より血管数は多くなってい たが，炎症性莒胞ではそのよらな傾向はみられなかっ た。

4. 炎症性䔶胞, 発育性琵胞ともに炎症があると樅型 血管が増加する傾向がみられた，炎症性雚胞の血管走行 は, 基本的には最内層は縦型, 最外層は水平型が優位で あり，最内層では炎症が鎮静化すると水平型血管の割合 が增加するものの，依然縦型が㕍位であった。これに対 し，発育性擎胞の血管走行はほとんどすべての部位で水 平型の優位が基本であり，これに炎症が加加ると最内層 では紟型血管が增加するものの水平型の唛位は保たれる が，最外層では縦型が主体となる傾向が歹られた。

5. 以上の結果より, 顎骨琵胞壁の血管走行の分析は, 


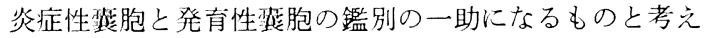
られた。

稿を終えるにあたり，終始ご想篤なるご指導，ご校閲 を賜りました口腔外科学第 1 教室中島民雄教授に心より 感謝の意を表しますまた本研究を遂行するにあたりここ 教示と直接ご指導を頂いた本学口腔解剖学第 1 教室小沢 英浩教授, 朝日大学口腔解剖学教室岩久文彦教授, 本学 口腔病理学教室福島祥紘助教授, 小千谷総合病院菌科上 田健先生に深謝致します。さらに，いろいろの面にわた りこ援助頂いた本学口腔病理学教室石木哲夫教授, 本学 口腔外科学第 2 教室大橋靖教授, 口腔解剖学第 1 教室, 口腔病理学教室, 口腔外科学第 1 教室, 口腔外科学第 2 教室の教室員各位に厚く扰礼申し上げます。

なお，本論文の要旨は第39回日本口腔科学会総会（昭 和60年, 仙台), 第 32 回日本口腔外科学会総会 (昭和 62 年, 東京), 平成元年度新潟断学会第 1 回例会 (新潟) に扒いて発表した。

\section{引用 文 献}

1) Pindborg, J.J. and Kramer, I.R.H.: Histological typing of odontogenic tumours, jaw cysts, and allied lesions. World Health Organization, Geneva, 1971, p 18-19.

2) Shear, M.: Cysts of the oral regions. 1st Ed, John Wright \& Sons Limited, Bristol, 1976.

3) Main, D.M.G.: Epithelial Jaw Cysts: 10 years of the WHO classification. J. Oral Pathol 14: 1-7 1985.

4) 石川梧朗, 秋吉正豊：口腔病理学 II, 第 6 刷 永末書店, 京都, 1979, 845 頁。

5）横林敏夫：非角化性原始性整胞扰上び類似顎骨 聚胞の臨床病理組織学的研究一非角化性原始性 整胞の存在意義について一。吅外誌 29 : 1090-1106 1983.

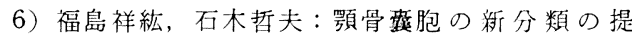
唱. 蔽医学誌 4：50-63 1985.

7) Murakami, T.: Application of the Scanning Electron Microscope to the Study of the Fine Distribution of the Blood Vessels. Arch. Histol Jap 32: 445-454 1971.

8) Murakami, T.: Vascular Arrangement of the Rat Renal Glomerulus. A Scanning Electron Microscope Study of Corrosion Casts. Arch Histol Jap 34: 87-107 1972.

9) Fujita, T. and Murakami, T.: Microcirculation of Monkey Pancreas with Special Reference to the Insulo-Acinar Portal System. A Scanning Electron Microscope Study of Vascular Casts. Arch Histol Jap 35: 255-263 1973.

10）采島澻也，村上宅郎，他：鋳型標本に上る肝血 管系の覞察（アカダザル）-1〜6医学のあゆみ 87: 403-414 (中付) 1973.
11) Fujita, H. and Murakami, T.: Scanning Electron Microscopy on the Distribution of the Minute Blood Vessels in the Thyroid Gland of the Dog. Rat and Rhesus Monkey. Arch Histol Jap 36: 181-188 1974.

12）入野昭三，小野哲也，他：Injection replica 法 を応用した走查電顕による骨䯣血管構榮研究一 の新しいアプローチ医学のあゆみ 88:2932941974.

13）江口季雄，大東康幸：合成樹脂鋳型に上る管采 統の立体病理学的研究法並びに組織切片封入法 に就いて。岐阜医紀 2：203-208 1954.

14）村上宅郎：微細血管分布機構研究のための鋳型 走查電子顕微鏡法 細胞 7: 11-18 1975 .

15）島田達生：樹脂注入と化学的消化法の併用に上 る微小循環の SEM 観察。細胞 2 13: 44-49 1981.

16) Nagato, T.: Scanning Electron Microscopical Image of Myoepithelial Cells. J. Electron Microsc. 27: 235-236 1978.

17) Evan, A.P., Dail, W.G., et al.. Scanning Electron Microscopy of Cell Surfaces Following Removal of Extracellular Material. Anat. Rec. 185: 433-445 1976.

18）村上正浩，杉田 新：塩酸コラゲナーゼ消化法 (Evan) の SEM 生物試料への応用之検討。稩 胞 13: 2-7 1981 .

19）日本病理学会編：病理技術 マニュアル5 病理 学領域に打外了電顕応用。医粎薬出版, 東京, 1985，83-92頁.

20）山崎一人, 渡辺陽之輔：電顕領域に打けるモル フォメトリーと画像処理一コンピュータによる 連続切片 3 次元再構築法も加之て一病理と臨床 4: 172-177 1986.

21）鳥脇純一郎：形態計量に扣ける画像解析装置の 利用。病理と臨床 4: 144-154 1986.

22）上原康生，小室辉昌，他：連続超莎切片儿上る 細胞の立体再構桇とその走查型電子䫓徵鏡によ る検討。細胞 11：2-10 1979 .

23) Furusato, M., Fukunaga, M., et al.: Twoand three-dimensional ultrastructural observations of angiogenesis in juvenile hemangioma. Virchows Archiv (Cell Pathol) 46: 229-237 1984.

24）上条鹤彦：口腔解剖学 3 ・脈管学。第 1 版アナ 卜一公社, 東京, 1969, 401-420頁。

25) Elias, H. and Pauly, J.E.: Human Microanatomy. 3rd Ed., F.A. Davis Company, Philadelphia, 1966. p 113-128.

26）㴖口史郎：図説組織学。第 1 版，金原出版，東 京・大阪・京都, 1983，121-147頁.

27) 市岡正道, 河村洋二郎, 他：隧学生理学. 第 1 版, 医萪菂出版, 東京, 1967, 93-109貢.

28）山田英智, 市川 厚, 他 ブルーム・フォー七 ッ卜組織学、第10版，広川毒店，東京，1979， p 411-446. 
29）山本敏行：基淮組織学，第 2 版，南江堂，查 京, 1970, 120-130頁.

30）鉿木 貢，下舘洋美：感染顎胞に対するア三 ノグリコシド系抗生物質「ネチリン」の局所療 法について一特に内容液酸素分圧の推移からみ た効果判定一診療と新薬 25：2173-2183 1988.

31）佐藤 昇, 後藤 完：血管内皮細胞 In vitro の 血管新生一そのメカニズムと応用一組織培㖉研 究 5: 81-94 1987.

32）雨宮功治，鉿木 潤，他：增殖型炎症時の血管 新生に扣けるPronase の作用機序. 日本薬理学 䧱誌 88: 279-288 1986.

33）鉿江 䱋, 小林忠義, 他：病理学総䛺第 2 版, 医学書院，東京，1960，444-450頁，550-555頁 557-559頁.

34) Clark, E.R. and Clark, E.L.. Microscopic observations on the growth of blood capillaries in the living mammal. Am. J. Anat. 64: 251 $-3011939$.

35）佐藤 昇, 沢崎嘉男, 他：ラットMyofibroblast の血管新生促進作用 增殖 - 遊走因子と Extracellular matrix の役割。動脈硬化 15：279-285 1987.

36）斉木秀彦：実験的創䭪治疲に打ける血管䉼生嘰
序。久留米医会誌 41：185-206 1978.

37) 吉塚光明：角膜血管新生機序に阙する形態的研 究，久留米医会誌 42：1-16 1979:

38）星子 力：消化管吻合術後の粘膜下層の血管新 生に関する電子顕碳 鏡的観察。久留米医会誌 47: 1091-1104 1984.

39) Cogan, D.G.: Corneal vascularization Invest. Opthal. 1: 253-261 1962.

40）信藤孝博, 西川義公, 他: 挝周外科処置後の㓣

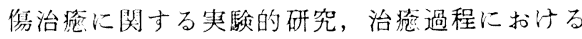
血管新生機序。日㳡保誌 30：1079-1094 1987.

41）三力淳男, 大石隆夫, 他. 肉芽組織と血管周皮 最䉼医学 33: 1900-1904 1978.

42) Schoefl, G.I.: Studies on inflammation. III . Growing capillaries: Their structure and permeability. Virchows Arch. Path Anat 337: 97-141 1963.

43) Schoef. G.I. and Majno, G.: Regeneration of blood vessels in wound healing. Advances in Biology of Skin 5: 173-193 1964.

44) Shear, M.: Cysts of the oral regions. 2nd Ed. Wright. PSG, Bristol London, Boston, 1983, p 26-33, p 70-72, p 96-100. 